\title{
RESPON PERTUMBUHAN SAGU (Metroxylon sagu Rottb) DENGAN PERENDAMAN ZAT PENGATUR TUMBUH IBA
}

\section{Kamsia Dorliana Sitanggang, Siti Hartati Yusida Saragih, Widya Lestari}

\author{
Program Studi Agroteknologi, Fakultas Sains dan Teknologi, Universitas Labuhanbatu \\ Jl. SM. Raja No. 126A Rantauprapat, Sumatera Utara \\ Email : kamsiasitanggang@gmail.com
}

\begin{abstract}
Sago is a plant produces high carbohydrate source. The problem of sagoo propagation by generative are limited number of seeds and low germination. Vegetative propagation of sago can be done through sago tillers, however, the very slow root growth will affect the ability of the sago to survive. One way to accelerate root growth is by administering IBA growth regulators. This study aims to determine the response to the growth of sago saplings by immersing IBA $(0,25,50,75) \mathrm{ppm}$. The results showed that the highest percentage of living plants was found in the $25 \mathrm{ppm}$ IBA immersion treatment with the percentage of live tillers $88.89 \%$. For the parameters of the number and length of roots and the highest plant height was also found in the $25 \mathrm{ppm}$ IBA immersion treatment with an average number of roots of $6.7,12.43 \mathrm{~cm}$ of root length and an average plant height of $49 \mathrm{~cm}$.
\end{abstract}

\section{Keywords: IBA, Root induction, Sagoo}

\section{PENDAHULUAN}

Sagu merupakan salah satu tanaman palmae penghasil sumber karbohidrat yang banyak tumbuh di dataran rendah atau rawa dengan sumber air yang melimpah. Sagu banyak digunakan sebagai bahan makanan, sumber daya energi serta bahan baku industri. Pada pembuatan makanan, sagu banyak digunakan untuk membuat mie, roti, kue kering, biskuit, kerupuk, kue basah dan kukis. Dalam dunia industri, pati sagu banyak digunakan sebagai bahan pembuatan gula cair, alkohol serta pembuatan plastik ramah lingkungan (Heryani \& Silitonga, 2017).

Sampai saat ini pengembangan agribisnis sagu belum banyak mendapat perhatian karena tanaman sagu belum banyak dibudidayakan. Upaya untuk meningkatkan teknologi budidaya sagu sampai saat ini masih terus dilakukan dengan banyaknya penelitianpenelitian terkait sagu (Adawiyah, R dan Muhammad, 2019).

Tanaman sagu dapat diperbanyak secara generatif yaitu melalui biji, akan tetapi perbanyakan melalui biji biasanya menghasilkan keturunan yang bervariasi. Faktor lain yang menyebabkan perbanyakan secara generatif jarang dilakukan yaitu jumlah biji yang terbatas dan kemampuan perkecambahan biji yang rendah sekitar 3,50-6,43\% (Karyanti, Yusuf Sigit, Teuku Tajuddin, Erwinda, Minaldi, 2016).

Sagu juga dapat diperbanyak secara vegetatif yaitu melalui anakan sagu (sucker), kan tetapi, kendala yang sering terjadi yaitu banyaknya anakan sagu yang mati karena pertumbuhan akar yang sangat lambat. Salah satu cara untuk menginduksi pertumbuhan akar 
adalah dengan pemberian zat pengatur tumbuh auksin diantaranya IBA. IBA dapat merangsang aktifitas perakaran dikarenakan kandungan kimianya stabil dan daya kerjanya lebih lama dibandingkan ZPT yang lain seperti IAA (indole acetic acid) dan NAA (naphthalene acetic acid)serta mempunyai aktifitas auksin yang lemah tetapi bila konsentrasi tinggi IBA dapat menyebabkan sel mengalami kematian (Romly \& Karyanto, 2019).

Penelitian ini bertujuan untuk melihat respon pertumbuhan sagu dengan perlakuan perendaman IBA pada beberapa taraf $(0,25,50$ dan 75) $\mathrm{ppm}$.

\section{METODOLOGI PENELITIAN}

\section{Lokasi dan waktu Penelitian}

Penelitian ini dilakukan di Lahan Percobaan Universitas Labuhanbatu pada bulan Juli 2017.

\section{Pengambilan Tanaman Sagu}

Sagu diperoleh dari daerah pare-pare desa Pulo Bargot Kecamatan Merbau. Pengambilan dilakukan dengan memisahkan anakan sagu dari induknya menggunakan tumbilang.Anakan sagu dibawa ke kampus Universitas buhanbatu untuk dilakukan percobaan (Gambar 1).

\section{Pengamatan}

Parameter yang diamati diantaranya persentase tanaman yang hidup, rata-rata jumlah dan panjang akar, dan rata-rata tinggi tanaman.

\section{HASIL DAN PEMBAHASAN \\ Persentase Hidup}

Salah satu indikator berhasil tidaknya memperbanyak tanaman secara vegetatif (anakan) adalah kemampuan tanaman untuk bertahan hidup.Kemampuan bertahan hidup ditandai dengan daun yang berwarna hijau, bertambahnya tinggi tanaman dan jumlah akar yang semakin meningkat (Gambar 2). Respon anakan sagu yang diberi perlakuan perendaman IBA $(0,25,50$ dan 75$)$ dapat dilihat pada Tabel 1.

Tabel 1. Persentase pertumbuhan anakan sagu

\begin{tabular}{ccccc}
\hline Perlakuan & $\begin{array}{c}\text { 0 } \\
\text { ppm }\end{array}$ & $\begin{array}{c}\mathbf{2 5} \\
\text { ppm }\end{array}$ & $\begin{array}{c}\mathbf{5 0} \\
\text { ppm }\end{array}$ & $\begin{array}{c}\mathbf{7 5} \\
\text { ppm }\end{array}$ \\
\hline \%Hidup & 22,22 & 88,89 & 77,78 & 22,22 \\
& & & & \\
\%Mati & 77,78 & 11,11 & 22,22 & 77,78
\end{tabular}

Persentase tanaman hidup tertinggi adalah perlakuan perendaman IBA $25 \mathrm{ppm}$ dengan persentasi $88,89 \%$ dan terendah tanpa pemberian IBA. Pemberian IBA dengan konsentrasi 300 ppm berpengaruh yang nyata terhadap persentasi hidup tanaman Grinops verstegii (Auri, 2016).

Selain kemampuan untuk menginduksi akar, pemberian IBA 1000 ppm mampu meningkatkan jumlah tunas pada sirih merah. Faktor lain yang mempengaruhi keberhasilan perbanyakan melalui anakan adalah perlakuan naungan di pembibitan, kedalaman penanaman, dan metode pemeliharaan bibit (Maulida et al., 2013).

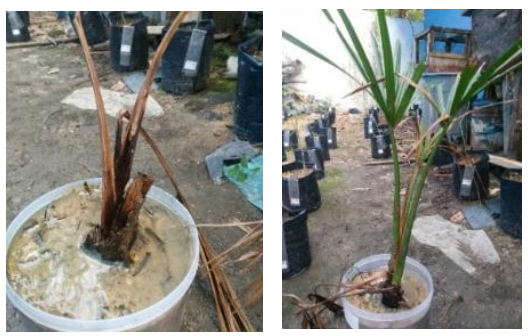

Gambar 2. Perbedaan morfologi tanaman sagu yang mati dan hidup; (A). Mati, (B) Hidup 


\section{Jumlah dan Panjang akar}

Salah satu faktor pendukung untuk meningkatkan keberhasilan dalam perbanyakan tanaman secara vegetatif adalah kemampuan dalam menginduksi akar.Akar merupakan tempat masuknya mineral (zat-zat hara) dari tanah menuju ke seluruh bagian tumbuhan. Hasil penelitian pada anakan sagu (sucker) yang direndam dengan menggunakan ZPT IBA menunjukkan bahwa perendaman sucker dengan menggunakan IBA dapat menginduksi bertambahnya jumlah dan panjang akar dibanding sucker yang tidak diberi perlakuan perendaman IBA (Tabel 2).

Tabel 2. Rata-rata jumlah dan panjang akar

\begin{tabular}{|c|c|c|}
\hline $\begin{array}{c}\text { Perendaman } \\
\text { IBA (ppm) }\end{array}$ & $\begin{array}{c}\text { Jumlah } \\
\text { akar }\end{array}$ & $\begin{array}{c}\text { Panjang } \\
\text { Akar (cm) }\end{array}$ \\
\hline $\mathbf{0}$ & 2,3 & 1,13 \\
\hline 25 & 6,7 & 12,43 \\
\hline 50 & 3,3 & 9,33 \\
\hline 75 & 2,9 & 2,53 \\
\hline
\end{tabular}

Rata-rata jumlah dan panjang akar terpanjang terdapat perlakuan perendaman IBA 25 ppm dengan rata -rata jumlah akar 6,7 dan panjang akar 12,43 cm. Pemberian IBA $25 \mathrm{ppm}$ pada tanaman nilam juga dapat meningkatkan jumlah akar dengan rata-rata 5,03(Dorliana, K. Ummi, 2016) .

\section{Tinggi Tanaman}

Salah satu ciri tanaman untuk bertahan hidup yaitu dengan bertambahnya tinggi tanaman.Kemampuan tanaman untuk bertambah tinggi dipengaruhi hormon yang terdapat didalam tanaman.IBA merupakan salah satu jenis zat pengatur tumbuh yang dapat menginduksi pertumbuhan akar juga mempengaruhi pertambahan tinggi tanaman pada beberapa jenis tanaman tertentu.

Tabel 3. Rata-rata tinggi tanaman sagu setelah diberi perendaman IBA

\begin{tabular}{ccccc}
\hline $\begin{array}{c}\text { Perlakuan } \\
\text { IBA (ppm) }\end{array}$ & \multicolumn{4}{c}{$\begin{array}{c}\text { Minggu Pengamatan } \\
\text { (MST) }\end{array}$} \\
\cline { 2 - 5 } & $\mathbf{1}$ & $\mathbf{2}$ & $\mathbf{3}$ & $\mathbf{4}$ \\
\hline $\mathbf{0}$ & 15 & 19 & 21 & 23 \\
$\mathbf{2 5}$ & 18 & 21 & 35 & 49 \\
$\mathbf{5 0}$ & 17 & 19 & 23 & 27 \\
$\mathbf{7 5}$ & 15 & 18 & 21 & 24 \\
\hline
\end{tabular}

Pada parameter tinggi tanaman juga memperoleh data yang sama, dimana rata - rata tanaman teringgi terdapat pada perlakuan perendaman IBA 25 ppm dengan rata-rata 49 $\mathrm{cm}$ pada umur 4 minggu setelah tanam. Pemberian IBA dengan konsentrasi $(25,50$, dan 100) ppm pada perbanyakan tanaman kumis kucing secara vegetatif juga tidak memberikan pengaruh yang nyata(Wiraswati, 2019) .

\section{KESIMPULAN}

Perendaman IBA 25 ppm dapat meningkatkan persentase hidup tanaman sagu $(88,89 \%)$, jumlah daun $(6,7)$ dan panjang akar $(12,43 \mathrm{~cm})$ serta tinggi tanaman $(49 \mathrm{~cm})$.

\section{DAFTAR PUSTAKA}

Adawiyah, $\mathrm{R}$ dan Muhammad, A. (2019).Karakteristik Produksi dan Pendapatan Pengolah Sagu (Metroxylon spp.) pada Agroekologi Tanaman Sagu yang Berbeda di Kota Kendari.J. Berkala Penelitian Agronomi, 7(2), 130-138.

Auri, A. (2016). RESPON PERTUMBUHAN STEK Gyrinops verstegii TERHADAP 
PEMBERIAN BERBAGAI TINGKAT KONSENTRASI HORMON IBA (Indole

Butyric Acid) Growth.Jurnal Silvikultur

Tropika, 06(2), 133-136.

Dorliana, K. Ummi, S. (2016). INDUKSI PERAKARAN NILAM (Pogostemon cablin Benth) MELALUI PEMBERIAN ZPT IBA (Indol Butyric Acid) Kamsia.Jurnal Agroplasma, 3(126), 2630.

Heryani, S., \& Silitonga, F. (2017). Penggunaan Tepung Sagu ( Metroxylon sp . ) sebagai Bahan Baku Kukis Cokelat. Journal of Agro-Based Industry, 34(2), 53-57.

Karyanti, Yusuf Sigit, Teuku Tajuddin, Erwinda, Minaldi, N. H. (2016). PENANGANAN ANAKAN MUDA PADA KULTUR EX VITRO UNTUK MENGHASILKAN BIBIT SAGU ( Metroxylon sagu Rottb.) SIAP TANAM. JURNAL BIOTEKNOLOGI \& BIOSAINS INDONESIA, 3(1), 13-19.

Maulida, D., Rugayah, \& Andalasari, D. (2013).Pengaruh Pemberian IBA (Indole Butyric Acid) dan Konsentrasi Naa (Naphthalene Acetic Acid) terhadap Keberhasilan Penyetekan Sirih Merah (Piper Crocatum Ruiz and Pav.).Jurnal Penelitian Pertanian Terapan, 13(3), 151158.

http://jurnal.fp.unila.ac.id/index.php/JA/art icle/view/1905

Romly, M. H., \& Karyanto, A. (2019). PENGARUH KONSENTRASI DAN CARA PEMBERIAN INDOLE-3BUTYRIC A CID ( IBA ) TERHADAP PERKECAMBAHAN PERTUMBUHAN DAN MANGGIS ( Garcinia mangostana L .). Jurnal Agrotek Tropika, 7(1), 257-264.
Wiraswati, S. dan K. (2019).Pengaruh Pemberian IBA dan Asal Stek Terhadap Pertumbuhan Vegetatif Kumis Kucing.11(2), 65-70. 